\title{
Wort and Wîse: Retextualization in Fifteenth and Sixteenth Century German Song Culture
}

\author{
Franz-Josef Holznagel
}

1 Some Reflections on the Effects of $d \hat{o} n^{1}$ Reuses and Contrafacts: Thinking on Two Levels and Clustering ${ }^{2}$

\section{$1.1 \quad$ Thinking on Two Levels}

Dôn reuses and contrafacts are classic forms of retextualization ${ }^{3}$ which enable two-level thinking, creating a characteristic effect. The text being heard or read (re-text, Level II) is related to the remembered pre-text (Level I). The aesthetic appeal of retextualization lies in the fact that the informed addressee recognizes the pre-text in the re-text and can compare the text presented (in performance or reading) with their knowledge of the pre-text. This opens up a dialogue with the tradition; in the process, the pre-text can be (partially) approved or (partially) contradicted.

Texts are always at the crossroads of divergent discourses. This embedding in previous orders of speech can be disguised (when authorship is presented as inspired by the aesthetics of genius). In contrast, retextualizations often emphasize their incorporation into traditions and capitalize on distinction from the previous aesthetic. In the case of lyric poetry, the two levels on which the recipient operates are again differentiated, because both the pre- and the re-text are usually combined with melodies. This yields particularly complex meanings that do not exist in the tradition of unsung genres. This production of meaning can be represented as a semiotic rectangle. ${ }^{4}$

1 Since there is no equivalent in English, the Middle High German dôn is used in this article, a term describing the reusable structure of metre and melody of a stanza. The purpose of this article is to show exactly how metre and melody were reused and what effects this could potentially have had.

2 Ich danke Kate Sotejeff-Wilson für die umsichtige wissenschaftliche Übersetzung ins Englische und Annika Bostelmann für die sorgfältige Durchsicht des Manuskripts.

3 On the term retextualization cf. especially Bumke and Peters (2005).

4 Cf. Holznagel (2005); Holznagel (2007). 


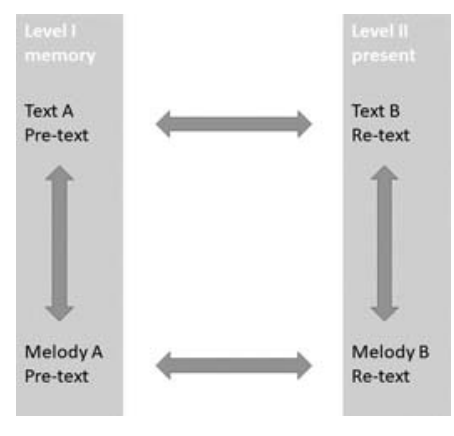

FIGURE 1.1 Semiotic rectangle of retextualization

Text and melody $B$ are accessible in the current vocal presentation, while the listener has to recall text A, its melody, or both. This creates a range of possibilities for comparing the four positions, each of which generates its own semantic effects. In addition to the semantics of comparing text $\mathrm{A}$ and $\mathrm{B}$, also present in unsung texts, the interactions between text B and the melodies A and B would have to be taken into account when considering re-texts of lyric poetry.

One important effect is that the combination of text A and melody A can lead to a veritable semanticization of metrical structures, because the contents, so to speak, rub off on the form. As a result, the music or even the metrical structure can be used as a discourse marker: When a recipient is accustomed to a certain relationship between word and sound, listening to a melody alone can evoke the idea of a particular thematic field without requiring exact knowledge of the original text associated with the melody.

\subsection{Literary and Musical Clusters}

Another characteristic of the retextualization of sung texts is the formation of literary and musical clusters. When texts are sung in the same dôn, and/or with the same melody, contrafact or tune reuse may create bridges to songs that are interconnected by formal characteristics, but can differ very much in terms of topic and content. Such clusters are peculiar entities because they do not form a definite centre and are constantly expanding. They also overlap with similar clusters (creating interference). While they can be very durable and encompass large geographical areas, the impact of the changes and innovations in media in the fifteenth and sixteenth centuries is revealing. ${ }^{5}$

5 Preferably these clusters should be analyzed more intensely, this kind of research could be based on Michael Curschmann's work (1970) on the Heselloher tradition. 
What do these literary and musical clusters look like in the fifteenth and sixteenth centuries? How does the semanticization of melodies and metrical structures affect clustering? To address these two questions, the reception history of the song Die welt hat ain thummen mut is analysed here. ${ }^{6}$

\section{A Pronounced Case of Clustering: The Reception History of the Droll Song Die welt die hat ain thummen mut}

A farmer goes out to bring his master a load of logs; his mistress is to receive a basket of eggs. ${ }^{7}$ When, at the court of his feudal lord, he sees the lady on the battlements, he cries out that he would sacrifice his horse and cart if he could spend time with the mistress. The lady takes him at his word, and so ir baider will ('their common will') is fulfilled (st. 3, v. 5). Then the brand new adulterer enters the courtyard and exclaims that he regrets the loss of his horse and cart because, after all, one (woman or log?) is like another (st. 4, v. 4-5: ich sprich: wie aine als die anderen sey, / mich rewet mein ro $\beta$ vnd mein wagen).

This most unkind statement must seem puzzling to the the farmer's lord who happens to be passing by, so he asks for an explanation. In this dangerous situation, the farmer resorts to a ruse that, on the one hand, obscures his act of adultery, but on the other, makes his speech act appear plausible: He claims that the lady had taken away his team because some of the logs he brought were crooked, but since the logs all burn in the same way once they are in the oven, he feels mistreated and asks his master to help him regain his mistress' favour (st. 6 and 7). The lord then asks his wife about the motives of her actions, and since she cannot openly admit to adultery, she returns the love-token to the peasant (st. 9).

This song originates in the mid-fifteenth century, as far as can be reconstructed from the tradition, probably in the Upper German region. It belongs to the literary tradition of droll songs (Schwanklieder), which are documented as

6 About this song see Bax (1935); Brednich (1983); Brednich (1973) 167-168; Brednich (1968); Böhme (1966) 170-171 (Die Welt hat einen thummen muot) and 537 (Een boerman); Erk and Böhme (1988) 444 (Die Welt die hat ein' dummen Mut) and 445 (Een boerman); Haapalainen (1976) 249-256; Holzapfel (2006) 322-323; Houtsma (2002) 157-158; Mone (1837); Ranke and Müller-Blattau (1987) no. 15 (43-45) 235-237; Roth (1977) 272; Van der Poel et al. (2004) 1, 8485 and 2, 109-110; Williams (1930); Winkelman (2003); Cf. Holznagel and Möller (2013) for a discussion of the following example in German.

7 The following sketch of the song action is based on the Upper German long version of Manuscript R (Rome, Biblioteca Apostolica Vaticana, Pal. Vat. IV. 228, fol. $59^{\text {rv }}$ ). This version has been edited by Williams (1930) (quoted) and Roth (1977): 272-273. 
early as the eleventh century in Latin manuscripts from the German-speaking area. These were only written down during the High Middle Ages and are increasingly recorded in the new media available in the fifteenth and sixteenth centuries. ${ }^{8}$ The text under discussion holds a special position within this tradition because it combines two independently established narrative schemata ('unnoticed adultery of a noble lady' and 'recovery of the goods lost in an amorous escapade'). ${ }^{9}$ Thus, it doubles the unexpected turnover of the action typical of the droll story.

A thoughtless utterance by the protagonist initiates both parts of the action. In both cases, this speech act has unforeseen consequences, which in the end have a positive effect on the farmer. First, his murmured wish to share a bed with the mistress leads to the unexpected amorous escapade, and then his other spontaneous remark that the lady is like any other woman leads to the recovery of the lost goods. The speaker in the first part of the text is merely a passive beneficiary, who seizes the moment, but then does not want to accept the disadvantages of the pleasures granted to him.

In the second part, the turn in the plot is based on the peasant's quickwittedness, more precisely on his ability to give a new meaning to a carelessly pronounced sentence (highly dangerous to the speaker) by stating a fictitious but plausible context to the addressee. On the one hand, this new meaning distracts him from the adultery that has just been committed (and thus defuses the explosive power of what is actually meant). On the other hand, it serves the peasant's material interests. The adulterer performs a decisive linguistic transformation, substituting the ambiguous statement, wie aine als die anderen sey

8 See especially the famous Modus Liebinc in the Carmina Cantabrigiensia, which is considered to be the earliest evidence of the widespread story of the snow child. For the German poetry of the thirteenth century cf. Reinmar $\mathrm{MF}^{38}$ no. LXIV, Neidhart HW 46,28 or Gottfried von Neifen KLD 15. no. XXXIX and no. XL. In the late Middle Ages droll songs are closely connected to the Neidhart reception, see especially the Neidhart manuscripts c (Berlin, Staatsbibliothek zu Berlin - Preußischer Kulturbesitz: mgf 779), d (Heidelberg, Universitätsbibliothek: cpg 696), f (Berlin, Staatsbibliothek zu Berlin - Preußischer Kulturbesitz, mgq 764) and w (Wien, Österreichische Nationalbibliothek, Cod. s. n. 3344), the droll story book about 'Neidhart Fuchs', and the authors Göli and Hans Heselloher, whose texts are oriented towards Neidhart. In contrast, this genre is also found in fifteenth and sixteenth century songbooks. The oldest remainig one is the song Es fur ein paur gen holz (Berlin, Staatsbibliothek zu Berlin Preußischer Kulturbesitz, Mus. Ms. 40.613, p. 91) in the Lochamer songbook, cf. Rolf Wilhelm Brednich (1973): 169-170, which does not mention the early evidence of the thirteenth century. Other examples can be found in Fichard's songbook (lost), in the manuscript Karlsruhe, Badische Landesbibliothek, Cod. St. Blasien 77 and in the Rostock songbook.

9 About the patterns cf. Roth (1977): 25, and for our droll song especially 43 and 272-273 (no. D 13). 
(in st. 4, v. 4), with the expression ain fuder stangen holtz (st. 6, v. 2), adding that some of the logs are too crooked: die seindt ain thayll zu krummen (st. 6, v. 3).

For the attentive listener and reader, this is a play on two meanings. Literally, the 'crooked log' merely means a trivial object, which ties in with the initial situation (a farmer supplying wood), an appropriate explanation of the enigmatic sentence. In a second meaning, however, the crooked branch is a sexual symbol referring back to the adultery that just occurred, so that there is a metaphorical relationship between the invented object and the real cause of the loss of the horse and cart. This has a comic effect on the recipient, who knows the facts and decodes the figurative meaning.

The metrical form of this droll song about adultery is divided into clearly distinguishable parts: A couplet with four stresses and male cadence is followed by two rhyming verses with three stresses and female cadence embracing a (male or female) orphan verse with four stresses, called the bridge. The verses are consistently upbeat $(\mathrm{U})$. The metrical pattern is therefore: $\mathrm{U} 4 \mathrm{~m}$ a / $\mathrm{U} 4 \mathrm{~m}$ a / $\mathrm{U}_{3}$ $\mathrm{f} \mathrm{b} / \mathrm{U} 4 \mathrm{~m}$ (or f) $\mathrm{x} / \mathrm{U}_{3} \mathrm{f} \mathrm{b}^{10}{ }^{10}$ This pattern agrees with two German stanzas of the Codex Buranus, is very widespread in the late Middle Ages and is known as the Lindenschmidt stanza (especially in the field of historical and political event songs). ${ }^{11}$ Within this family of tunes, the songs that go back to the droll story about adultery constitute a relatively well-defined group, ${ }^{12}$ because unlike other texts with the same tune, they have a melody that changes slightly in the course of the tradition, but always has the same basic musical structure: It is usually set in Dorian mode and its structure clearly supports the metrical division of the text. Only the first two verses are combined into a larger arc. With regard to the later versions, it should be noted that the melody was originally composed without repetition of identical components and solely based on the the combination of similar structures (especially in the lines 3 to 5 ) ${ }^{13}$

The text of the droll song has been handed down in three versions. They differ markedly in their written language and their macrostructure: The first version is written in Upper German language and is represented by ten stanzas

10 Explanation of the formula: $\mathrm{U} 4 \mathrm{~m}$ a / $\mathrm{U} 4 \mathrm{~m}$ a $=$ Two rhyming verses with upbeat and four stresses and ending in a stress, $\mathrm{f}=$ verse ending in an unstressed syllable, $\mathrm{x}=$ verse without rhyme, that is, an orphan verse.

11 Wachinger (1985).-Cf. also the articles by Seláf and Steinkamp in this volume.

12 However, there are overlaps with another song group in the Lindenschmidt dôn, centred around the love song $\mathrm{Ob}$ ich schon arm und elend bin, for which a quite similar melody has been preserved, so one could speak of two overlapping clusters of texts in similar metric structures (Tonfamilien).

According to the earliest evidence of the melody, the Glogau songbook. 
in the housebook (Hausbuch) of Simprecht Kröll ( $\mathrm{R}=$ Rome, Biblioteca Apostolica Vaticana, Pal. Vat. IV. 228, fol. $59^{\mathrm{r}-\mathrm{v}}$; Augsburg $1515^{-1522)} .{ }^{14}$ The final stanza is characteristic of this version (st. 10), and is missing in the other surviving texts. In it, the narrated event is ironically stylized as a fall in the relationship between the estates: no nobleman could trust a peasant after this adultery. According to the readings indicated in the edition, this version also includes trial pen strokes (probatio pennae) in an incunabulum (Tübingen, University Library, Ce $197 \cdot 2^{\circ}$, fol. $1^{\text {a }}$, Upper German after 1486 ), which, however, quotes only the first stanza of the song. ${ }^{15}$ This may be due to the sporadic, incomplete method of recording, but it may also reflect the tradition of only recording the incipit, or first stanza, in music manuscripts (see further).

The second version can be found as no. 15 in the Rostock songbook (Rostock, Universitätsbibliothek, Mss. Phil. 10o/2, fol. $16^{\mathrm{r}}-17^{\mathrm{r}}$, Low German, third quarter of the fifteenth century). ${ }^{16}$ It has been recorded in the Low German territories and shows two additional stanzas to R. The first one (no. 15, vv. 46-50) again mentions the lady at the end of the song: She gives the horse and cart back to the peasant, but not without encouraging him to repeat their adultery. In doing so, she cleverly resorts to the double coding of the crooked wood introduced by the farmer himself: ach kum her weder, wen du wult, / brinck vns dat krumholt vaken! The second additional stanza (no. 15, v. 51-55) mentions a hertich hinrik ('duke Henry') who sang or transferred the preceding song and was often seen in Brunswik ('Brunswick' in Lower Saxony).

The third version is first attested in the Antwerp songbook (Wolfenbüttel, Herzog August Bibliothek, A 236.5 Poet., Antwerp 1544). ${ }^{17}$ Thereafter, between 156o and 1640, it is found in three Dutch songbooks (the Oudt Amsterdam

14 Edition by Williams (1930) 143-145 and Roth (1977) 272-273. About the manuscript see RSM 1 (1986) vol. 1, 250.--Meyer (1989) 406-428 and 613-620.

15 Edition by Mone (1837). This is followed by inaccurate and varied printed versions by Böhme (1966) 170 (as a note to no. 82 ${ }^{\mathrm{a}}$ ) and Erk and Böhme (1893) 444 (as a note to no. 127 $7^{\mathrm{a}}$ ). Mone does not indicate which incunabula he used. I would like to thank Dr Gerd Brinkhus of the Universitätsbibliothek Tübingen for identifying it (by letter).-Cf. also Brednich (1983) and Roth (1977) 272-273.

16 Edition by Ranke and Müller-Blattau (1987) no. 15. About the manuscript see Heller, Möller and Waczkat (2000); Heydeck (2001) 128-132; Holtorf (1992); Holznagel and Möller (2003); Holznagel (2010). For more information on the Rostock songbook see http://www .rostocker-liederbuch.de accessed on 23 April 2018.

17 Edition (with bibliography) by Hoffmann von Fallersleben (1855) 5of., no. xxxv; Joldersma (1983) 1, 39-40 and 2, 71-72; Van der Poel et al. (2004) 1, 84-85 and 2, 109-110. About the printed edition cf. De Bruin and Oosterman (2002) no. T 1539, Mo179; Koepp (1929); Tervooren (2006). 
Liedboek, ${ }^{18}$ the collection Amoreuse liedekens ${ }^{19}$ and the Haerlems Oudt LiedtBoeck ${ }^{20}$ ), and also provides the basis for the farce Boere-klucht van Teeuwis de boer en men juffer van Grevelinckhuysen ${ }^{21}$ by the surgeon and poet Samuel Coster, printed in Amsterdam in 1627. On the macrostructural level, it diverges significantly from both the Rostock songbook and Simprecht Kröll's housebook: The third version lacks the stanza which explains the lady's willingness to return horse and cart with her fear of loss of honour, ${ }^{22}$ which is handed down in both the Upper German and Low German traditions. ${ }^{23}$ It is also important for the relationship between the three versions that the Dutch texts do not contain the final stanza from the Rostock songbook (no. 15, v. 51-55) or the last stanza from Simprecht Kröll's housebook (st. 10). But the Low German text (unlike in the Upper German tradition) does include the lady's final speech asking the farmer to come back. ${ }^{24}$

This sketch of the reception history reveals that the dôn Die welt die hat ain thummen mut circulated in three textual versions, which are attested from the end of the fifteenth century to the mid-sixteenth century in three large linguistic areas, the Upper German, the Low German, and the Dutch-Flemish. ${ }^{25}$

None of the examples mentioned so far recorded a melody for the droll song. This is no coincidence, as in the media formats used in all these cases it is possible, but not compulsory, to record notation. The text is written down (in whole or in part), but the melody belonging to the song usually is not. Knowledge-

18 Berlin, Staatbibliothek zu Berlin - Preußischer Kulturbesitz, Zf $7788 \mathrm{R}$ (lost).-Cf. Houtsma (2002) 157-158 and 16o, footnote 9.

19 Cf. Klatter (1984) 34-35.

20 Den Haag, Koninklijke Bibliotheek, ${ }_{1 C}$ 28. - Cf. Houtsma (2002): 157-158 and 16o, footnote 8.

21 Cf. Kollewijn (1883) 68-70 (vv. 1706-1755).

22 Cf. Ranke and Müller-Blattau (1987) no. 15, vv. 46-5o, and Williams (1930) 143-145, st. 9.

23 Surely a later ingredient is the last verse in the version from Coster's Boere-klucht van Teeuwis de Boer, which describes how the farmer sings met luyder keele ('full-throatedly') out of joy about his coup.

24 Cf. Van der Poel et al. (2004) no. 35, st. 9.

25 The starting point of the tradition and the concrete distribution channels, however, are more difficult to reconstruct. The linguistic and literary forms of the texts give some indications. Thus, the Rostock version shows a linguistic level which can only be explained by an Upper German original being adapted into Low German. The Antwerp songbook was probably also adapted from Upper German language. Moreover, Brednich supposes that the Rostock songbook acted as a link between the Upper German and Dutch traditions. This consideration is based primarily on literary evidence (cf. Brednich [1968] $79-80$ ), this would be worth discussing again in the light of a precise linguistic analysis. 
able recipients have to recall it for themselves. This gradually changes in the songbooks of the fifteenth century, which have a greater proximity to musical performance and therefore more often include musical notation. The Rostock songbook offers a melody only for about half of the songs, for example; thus, even in this medium, the notation of music clearly remains optional. This remains the case even in the sixteenth century, as shown by printed collections such as the Antwerp songbook. The situation changes fundamentally if one considers the different arrangements of our droll song. Overall, they can be classified into three groups:

(a) reception of the song in the sophisticated musical culture of the fifteenth and sixteenth centuries,

(b) secular and spiritual contrafacts, and

(c) transformation of the song action into a dramatic farce.

\subsection{The Reception of the Song in the Sophisticated Musical Culture of the Fifteenth and Sixteenth Centuries}

The first group contains three demonstrable cases of the song entering a more sophisticated musical culture. The three-part composition in the manuscript Glogau songbook ${ }^{26}$ dates back to the fifteenth century, and from 1537 onwards, Schöfer and Apiarius published the song in the various editions of their printed songbook. ${ }^{27}$ The five-voice setting in this songbook is attributed to a named composer, Thomas Stoltzer. ${ }^{28}$ From 1544 onwards, melody and text quotes from an unknown version of the song can be found in three parts of Wolfgang Schmeltzl's collection of polyphonic quodlibets, that is, three literary and musical montages that create a new, polyphonic whole from splinters of widely used dône. ${ }^{29}$

These revisions radically alter the balance between music and text: The text often only quotes the first stanza, sometimes even just a single line; in contrast, a comparatively differentiated system, namely various types of mensural

26 Kraków, Biblioteka Jagiellońska, Mus. ms. 40o98, quer $4^{\circ}$, no. 256 . Edition of the song parts by Ringmann and Klapper (1936) 10, no. 12 (melody with the text from the songbook by Schöffer and Apiarius [see below]) and 124 (commentary). About the manuscript see Fink and Salmen (1995); Sappler (1981).

27 Munich, Bayerische Staatsbibliothek, Mus. pr. 39 (Beibd. 2). Edition by Moser (1967) 169175, no. 55.-About the printed songbooks see Bruns (2008).

28 About Thomas Stoltzer see Hoffmann-Erbrecht (1964) Schmidt-Beste (2006).

29 Munich, Bayerische Staatsbibliothek, Mus. pr. 453.-Edition by Flotzinger (1990) Quodlibet no. VI, 44-55; Quodlibet no. VII, 56-63; Quodlibet no. XX, 122-133. About Wolfgang Schmeltzl see Bienenfeld (1904) and Flotzinger (2005). 
notation, are used to record the melodies. This goes hand in hand with a typical change in layout: The vertical text manuscript is replaced by a combination of several printed booklets in horizontal format, each of them only containing the melody of a single voice. This transition to partbooks is quite clearly explained by a change in usage. Previously, individual songs and textless songbooks had largely been recorded for archives and not necessarily been used for performance. In contrast, the new partbooks were designed for practical use in musical circles: Each musician or singer could easily find the melody in the desired range and the horizontal format facilitated an overview of the sequence of notes.

This tradition developed within the manuscript culture, as the example of the Glogau songbook shows, before entering Gutenberg's new world, after the initial difficulties with musical notation were overcome. In this context, the above-mentioned 1537 first edition of the songbook by Schöffer and Apiarius should be emphasized. It is considered one of the earliest examples of completely printed staves; ${ }^{30}$ previously, a combination of empty staves and handwritten music notes ${ }^{31}$ were used..$^{32}$

The adaptation of the droll song by sixteenth-century composers is thus characterized by a different treatment of text and music. They take the text, and possibly modify it slightly, but fundamentally change the musical aspect of the song. This form of retextualization, contrafacture, the technique of writing new texts to given melodies, is thus the direct counterpart to the procedure presented in the following section. ${ }^{33}$

$30 \quad$ About musical notation in print see Staehelin (2003).

31 Although musical notation could already be integrated into printing technology, handwritten recordings of polyphonic songs were still common throughout the whole 16th century. Concerning our droll song's tradition this phenomenon can be illustrated with regard to the music manuscript Berlin, Staatsbibliothek zu Berlin - Preußischer Kulturbesitz, Mus. ms. 40.190 which is a handwritten copy of Schmeltzl's printed collection of quodlibets.

32 Another shift applies to the status of authors and composers: While the librettist remains anonymous, the composer is often mentioned by name. Thomas Stoltzer even turns the song text into a veritable ego document, altering the last line of the first stanza so that his surname appears as rhyming word. This indirect marking of authorship is additionally underlined by repeating the fifth verse in Stoltzer's version, creating a stanza structure of six lines.

33 There is an abundant amount of literature concerning contrafacts. Exemplary, some titles should be listed here: Berthold (1918); Gennrich (1965); Hennig (1908); Lipphardt (1967); Mertens (2005); Pelnar-Zaiko (1984); Ruberg (1984); Schiendorfer (1995); Verweyen and Witting (2000). 


\subsection{Secular and Spiritual Contrafacts}

The significance of the contrafact for sixteenth-century song culture is well known. However, the focus is usually on the technique, related to Martin Luther and others, of singing newly written religious texts to the melodies of wellknown secular songs. It is less well known that secular texts have also always been linked to the melodies of earlier secular songs. In the reception history of the song about the clever peasant at least four (very different!) cases of secular retextualization can be demonstrated.

The first case is a song that appeared in an Erfurt songbook in $1529^{34}$ and complains about the pernicious influence of a stoltzen meydleyn ('proud young woman'), who presents herself to the male observers in the rose meadows and would not be satisfied by any good marriage (incipit: Ich woelt gern singen vnnd weyß nicht wie). It belongs to the genre of scolding songs (Scheltlieder) and carries parodic features because it reverses the traditional love constellation of German courtly lyric.

In contrast to this, the text printed about thirty to forty years later for the song WAs woellen wir aber heben an ${ }^{35}$ belongs to the historical and political genre. The text was passed down in a song booklet that was then integrated into a larger miscellany book with sixteenth-century printed matter. Its author, Nicholas of Brunswick, is named but otherwise completely unknown, and it deals with the execution of the mercenary Niklas Lang in Krems. Nevertheless, it builds an enlightening thematic bridge to the Erfurt printed edition by remarking that one should refrain from dealing with the beautiful frewlein ('young ladies'), because such contact has only brought disgrace.

The third secular contrafact is a rather conventional medieval courtly love song (Minnelied), which asks for God's assistance against the envious and contemptuous (incipit: Ob ich schon arm vnd elend bin / noch trag ich einen steten $\sin ) \cdot{ }^{36}$

34 Zwickau, Ratsschulbibliothek, 125 30.5.20. (27). Edition: Altdeutsches Liederbuch, ed. by Böhme (1877) 284-286, no. 201 and Deutscher Liederhort, ed. by Erk and Böhme (1988) vol. II, 641, no. 839-840.

35 Colmar, Bibliothèque de la Ville, CPC $75^{2}$ XVI . Cf. Unbekannte Ausgaben, ed. by Heitz (1911) and RSM (1985), vol. 1: 541.

36 Jena, Universitätsbibliothek, 12 Bud. Sax. 6 (24). The song belongs to another group of songs in the Lindenschmidt dôn, which are characterized by the incipit $O b$ ich schon arm und elend bin. It is revealing that the title page indicates a direct reference to the song of the clever peasant: Schoene Lieder Drey / | Das Erste / Ob ich schoen arm vnd | elend bin /Jm thon / Die Welt die | fuort ein dummen mut.—Cf. Das Ambraser Liederbuch, ed. by Bergmann (1962) 24-25, no. XXVII and 328-331, no. ccXXVII. Altdeutsches Liederbuch, ed. by Böhme (1877) 537. no. 431; Deutscher Liederhort, ed. by Erk and Böhme (1988) vol. 2, 
The fourth secular contrafact, the song FVhrleut die han einen guten mut, found, for example, in the Ambras songbook of $1582,{ }^{37}$ can also be classified (like the song of the clever peasant) as a droll song, but is particularly macabre: It tells the most unsavoury story of how some unreliable waggoneers harm themselves because they drink stolen wine from a barrel in which a corpse had been hidden to save the customs for its transfer.

These are far from the only examples of secular contrafacts. Rather, the Upper German tradition is transformed several times (apparently independently of each other) into spiritual song in the sixteenth and early seventeenth centuries. The earliest adaptation can be found in the works of Adam Reißner, ${ }^{38}$ who was committed to the teachings of the Silesian reformer Caspar Schwenckfeld von Ossig. Reißner wrote a large number of hymns for the Schwenckfeld community, with both new and old melodies. ${ }^{39}$ In this context, the song Von der vnrainen welt, which already referenced the peasant song with its incipit (Die well die hatt ain thumen mut), ${ }^{40}$ received a melody coinciding with the tenor voice in the Glogau songbook and in Stoltzer's version.

Adam Reißner's songbook was not printed but circulated in handwritten copies in the sixteenth century. In the subsequent period its reception extended beyond Europe, as members of the Schwenckfeld community emigrated to America. Reißner's contrafact of the song about the clever peasant was copied there again and again until the second half of the eighteenth century; it is possible to prove an uninterrupted chain of transmission from 1554 to $1758 .{ }^{41}$

552, no. 747; Forster, ed. by Gudewill et al. (1964-1997) Teil 5, 161-163 (text and melody) and 184 (commentary); Holzapfel (2006) 1173-1174; Volks- und Gesellschaftslieder, ed. by Kopp (1905) vol. l, 43, no. 38; Forster, ed. Marriage (1903) 204, no. XLIX (text) and 265-266 (commentary).

37 Vienna, Kunsthistorisches Museum, Inv. no. 5410.-Das Ambraser Liederbuch, ed. by Bergmann (1962) no. 134, 161-162; Cf. Holzapfel (2006) 618. About the Ambras songbook and the other Frankfurt print editions of 1578-1618 cf. RSM, vol. 1 (1985) 398-401.

38 Reißner, ed. by Janota and Evers (2004) vol. 2, 10-21 and 38-46 and 24-37 (about Schwenckfeld).

39 Adam Reißner's songbook is preserved in several manuscripts close to the author: Augsburg, Universitätsbibliothek, Cod. 1. 3. $4^{\circ} 10$ (East Swabian, around 1554). Wolfenbüttel, Herzog August Bibliothek, Cod. Guelf. 76.13 Aug $2^{\circ}$ (Upper German, 1596). Ulm, Stadtbibliothek: Hs. 6729-6734 (Upper German, 1597). Cf. Reißner, ed. by Janota and Evers (2004) vol. 2, 63-70 and 89-112 and 112-135. About the songs of the Schwenckfeld community in general see Evers (2007).

40 Cf. Augsburg, Universitätsbibliothek, Cod. 1. 3. $4^{\circ}$ 10, fol. 186r. - Facsimile in: Reißner, ed. by Janota and Evers (2006) vol. 1.

41 Cf. Reißner, ed. by Janota and Evers (20o6) vol. 2, 468; Kadelbach (1976). About the reception of German hymnals in North America in general see Holzapfel (1998). 
In addition to Adam Reißner's song Von der vnrainen welt, at least two other spiritual contrafacts are known from Upper German territories. One of these is the Geistliche Ackermann ('Spiritual Ploughman'), an allegorical song about Christ. It appeared four times and in slightly varied form in song booklets between 1560 and 1600,42 and then entered various hymnals at the beginning of the seventeenth century in an expanded version (such as Beuttner's 1602 hymnal). ${ }^{43}$ The other one are various Upper German versions of the lament about the state of the world (Weltklage), Die welt die hat ein thummen mut, that circulated between 1560 and $1600 .{ }^{44}$ Some versions are attributed to the Meistersinger and reformatory songwriter Martin Schrot ${ }^{45}$ of Augsburg. A variant of the melody found in Schöffer and Apiarius ${ }^{46}$ was adopted in Scandinavian hymnals of the seventeenth and eighteenth centuries, showing that the reception history of the song does not end in the early 1600 .

In Flanders and the Netherlands too, the secular dôn underwent repeated contrafacts. Two thematically related spiritual transformations are noteworthy; these address the theme of world renunciation and Christ as saviour and can be found in the oldest printed Dutch collection of spiritual music with notes, the Deuoot ende profitelijck boecxken, published in Antwerp in 1539 by Simon Cock. ${ }^{47}$ Again, the melody shows many structural similarities to the tenor part in the Glogau songbook. Another contrafact is found in the collection of

42 Berlin, Staatsbibliothek zu Berlin - Preußischer Kulturbesitz, Yd 7831, no. 41. Berlin, Staatsbibliothek zu Berlin - Preußischer Kulturbesitz, Hymn. 502o. Berlin, Staatsbibliothek zu Berlin - Preußischer Kulturbesitz, Hymn. 5034. Bern, Universitätsbibliothek, zв Rar 315: 55 (Rar. Pf. Müller, Langnau, no. 5o). Editions of single versions in: Deutscher Liederhort, ed. by Erk and Böhme (1988) vol. III, 840, no. 2144 (with a melody from Berlin, Staatsbibliothek zu Berlin - Preußischer Kulturbesitz, Ms. mus. Z 98); Das deutsche Kirchenlied, ed. by Wackernagel (1841) 578, no. 681. Cf. Holznagel and Möller (2013).

43 Innsbruck, Jesuitenkolleg Bibliothek, Nr. 42214. Facsimile: Beuttner, ed. by Lipphardt (1968) fol. $117^{\mathrm{v}}-119^{\mathrm{r}}$.

44 Colmar, Bibliothèque de la Ville, CPC $75^{2}$ XVI . Heidelberg, Universitätsbibliothek, F 709. Heidelberg, Universitätsbibliothek, F 1821. Heidelberg, Universitätsbibliothek, F 4070. Heidelberg, Universitätsbibliothek, F 5287. The whole group has not been edited yet. Cf. Holznagel and Möller (2013).

45 About Martin Schrot see RSM (1989) vol. 12: 49 and reg. and Kugler (1991) 407-408.

46 Cf. Haapalainen (1976) 249-256.

47 Brussels, Koninklijke Bibliotheek / Bibliothèque royale, L.P. 7795. Edition: Een devoot ende profitelyck boecxken, ed. by Scheurleer (1889) no. 78 (Die sinen voet set in eenen doren) and no. 79 (DIe mensch is seer dom ghesint). Cf. De Bruin and Oosterman (2002) vol. 1, 145, T1374 and 123, T1083 and (about the collection) vol. 2: 779 (D161/DEPB1539). Knuttel (1974) 70-73 (http://www.liederenbank.nl/liedpresentatie.php?zoek=3934\&lan=nl and http://www.liederenbank.nl/liedpresentatie.php?zoek=3935\&lan=nl accessed on 23 April 2018). 
the Souterliedekens, which translate the complete Psalter into Dutch rhymes and underlay them with partly borrowed, partly newly composed melodies. Together with the Deuoot end profitelijck boecxken, which is a year older, these constitute the largest printed archive of Dutch-Flemish spiritual lyric poetry of the sixteenth century. In this archive, Psalm 86 is set to music by means of a slightly modernized version of the Boerman's melody. ${ }^{48}$

In most cases spiritual and secular transformations are handed down in small song booklets with a maximum of four sheets. These booklets consist of a more or less decorated title page and two to three songs with similar content. This format lacks musical notes. On the title page or with each song, however, there is a note about the melody in which the texts are to be sung. This is a similar split between written text tradition and oral tradition of the melody to the one often seen in manuscripts of the fifteenth century. Such song booklets could be integrated into larger volumes-revealing the literary interests of the collector. Famous examples of these bookbinder symbioses include Jörg Dürnhofer's songbook, dated about $1515,{ }^{49}$ and the Weimar songbook dating from about $1537 .{ }^{50}$ In the reception history of the song of the clever peasant, this tradition type is represented in a miscellany at Colmar town library, ${ }^{51}$ composed of Strasbourg printed matter dating from the second half of the sixteenth century and containing various contrafacts of our droll song. ${ }^{52}$

Even though the tradition of contrafacts is dominated by song booklets without a melody, other formats can be found. The handwritten copies of Adam Reißner's hymnal are especially interesting because they represent the type of songbook with melodies associated with an author which existed from the fourteenth century (for example in the Heinrich Laufenburg Codex, which was

48 Emden, Johannes a Lasco-Bibliothek, Theol. $8^{\circ}$ o795 H. Souterliedekens, ed. by Biezen and Veldhuyzen (1984) 197-198; Souterliedekens, ed. by Mincoff-Marriage (1922) no. 14, 34-36 and no. 19, 42-43.-De Bruin and Oosterman (2002) vol. 1, 546, T 6527 (http://www .liederenbank.nl/liedpresentatie.php?zoek=13638\&lan=nl accessed on 23 April 2018). About the tradition see especially Scheurleer (1898); De Gier (1987); Lenselink (1959); Wiora (1953) 442-443 and 447.

49 Erlangen, Universitätsbibliothek, Inc. 1446a.—Edition: Dürnhofers Liederbuch, ed. by Schanze (1993).

50 Weimar, Herzogin Anna Amalia Bibliothek, 14.6: 6oe.-Edition: Das Weimarer Liederbuch, ed. Kratzsch (1976).

$5^{1}$ Colmar, Bibliothèque de la Ville, CPC $75^{2}$ XVI.

52 Cf. the miscellany Bern, Universitätsbibliothek, zв Rar 315:55 (Rar. Pf. Müller: no. 5o) with an Alemanic version of the 'Spiritual Ploughman'. Single sheets emerged slightly earlier than the song booklets. However, there are no traces of the song of the clever peasant in this format. 
unfortunately burnt in Strasbourg in 1871) ${ }^{53}$ Why did the hymn composer and his companions reuse such a long-established tradition? Surely because this hymnal was never planned for the general public, but intended for internal teaching use in the Schwenckfeld religious community, which was severely criticized and later literally persecuted. This hypothesis is supported by the fact that the other extant texts of Reißner's collection are also in manuscript, not printed, form.

In direct contrast to this, the 1602 Beuttner hymnal and the older Flemish collections show similarities to Reißner's hymnal in their layout, but were printed with the intention to reach as large an audience as possible. These printed collections could either be used in church services (in the case of Beuttner's hymnal) or for private paraliturgical devotion (assumed in the case of the Flemish collections). In contrast to Reißner's songbook, these three media made it possible for the songs they contain to be distributed widely. This is particularly true for the extraordinarily successful Souterliedekens, which went through multiple editions even in the first year of publication and were reprinted so often until 1564 that they are by far the most popular collection of spiritual Dutch-Flemish lyric poetryin the sixteenth century.

\subsection{Transforming the Song Action into a Dramatic Farce}

Samuel Coster's dramatic farce Boere-klucht van Teeuwis de Boer, en men Juffer van Grevelinckhuysen is directly related to the Antwerp songbook. The farce was performed for the first time in 1612 for the Amsterdam Chamber of Rhetoric (Rederijkerskamer) and was printed from 1627 onwards. It not only directly makes use of the plot of the droll song, but even quotes the dôn completely at the end to show the relation between re-text and pre-text. ${ }^{54}$

\section{Reasons for the Success of the Song Die welt die hat ain thummen mut}

The latest research indicates that the droll song is extant in three manuscripts and four early print editions from three major linguistic areas. Furthermore, there are three reworkings into polyphonic partsongs dating from the sixteenth century, quite a few spiritual and secular contrafacts and a play based

53 Strasbourg, Bibliothèque nationale et universitaire, Cod. *B $1214^{\circ}$. Wachinger (1985).

54 Den Haag, Koninklijke Bibliotheek, 447 G 83.—Edition: Coster, ed. by Kollewijn (1883) 6870, vv. 1706-1755. 
on the plot, not forgetting the (largely overlooked) late reception in the seventeenth and eighteenth centuries, which extends to Scandinavia and the New World. ${ }^{55}$

Such frequent usage of a secular dôn is not at all unique in the fifteenth and sixteenth centuries (see the reception history of Hans Heselloher's song Von den üppiclichen dingen $),{ }^{56}$ but is nevertheless such an unusual case overall that it is worth considering the reasons behind this success story.

The extensive distribution of the song and its retextualizations are primarily due to its strophic form; the generally familiar metric frame of orientation facilitates memory and recognition greatly. Furthermore, one might assume that using this dôn made genre changes easy, especially in the transition from sung farce to historical and political song: Since the Lindenschmidt dôn is generally introduced as a metric structure for texts concerned with contemporary history, it is not surprising that Nikolaus of Brunswick worked with this strophic form for his political song and used the melody known from the droll song for it.

The succinctness and quality of the melody, which was composed in one piece and for a solo singer, could also be a reason for its rich reception history. Like the strophic form, these features facilitate communicative memory through recognition, effect and enable easy modification and further development. On the one hand, the melody is so complex and appealing that it could inspire a composer like Thomas Stoltzer to create a polyphonic partsong based on it. On the other hand, the reception of the melody by Adam Reißner or in the Dutch-Flemish collections shows that it was not difficult to transfer the original melodic sequence to a musical structure suitable for choral singing. ${ }^{57}$

Furthermore, the melody of the song about the clever peasant made a strong semantic impression because of its connection to the droll story of adultery that it was perceived as a musical signature of a farce. This melody could have been especially linked to the idea of a world turned upside down. With this in mind, songs with similar content concerning the inversion of the normal rules may also have been based on this melody. The song about the stoltzen meydleyn

55 Cf. Reißner, ed. by Janota and Evers (2004) vol. 2 468; Haapalainen (1976); Houtsma (2002).

56 Cf. Heselloher, ed. by Curschmann (1970).

57 A detailed analysis of the melodies would demonstrate this. Cf. Holznagel and Möller (2013). The melody of the droll song was modified especially by targeted reductions in ambitus or regular repetitions arose because parts of the melody are so similar. In addition, since the melody set is in Dorian mode, and the initial part is so closely related to well-known pieces of Gregorian chant, such as the Rorate coeli, it simply calls for spiritual contrafacture. 
does not play on the superiority of the inferior but clever man, but on the prostitutes' cunning. The gender constellation is therefore different. The waggoneer's song in the Ambras songbook is all about losing and regaining the cart and the self-induced misery of dishonest hauliers whose punishment re-establishes the disrupted order.

It is highly likely that the melody served as a contrast for texts seeking to distance themselves from the original associations by using hyperbole. Thus, the spiritual ploughman is explicitly opposed to the secular peasant. Additionally, the first lines of the text sound like a proverb: Die welt die hat ain thummen mut, / für war es thut die lenge kain gut ("The world is in a silly mood, which won't be good in the long run'). This serves not only as an incipit for secular songs relating surprising anecdotes, but also as an opening for spiritual songs, since the assumption that the way of the world has changed is a fixed topos in religious admonition. This topos is present, for instance, in Adam Reißner's song about flight from and critique of an impure world; this is clearly suitable for the Schwenckfeld community, which defined itself as cut off from the world. Persecution by an evil world is proof of belonging to the chosen people.

In a somewhat more traditional way, this theme also appears in the Weltklage by Martin Schrot and the Devoot ende profitelyck boecxken (in relation to a general contempt of secular songs).

Finally, the plot of the droll story itself may be another factor which influenced distribution positively. The action is at least the basis for a special form of reception, that is, Samuel Coster's transformation of the peasant song into a dramatic farce. This transition from droll song to comic performance can be explained in a way that the unforeseen change in the plot is not unique to one type of text, but a structural principle found in almost every genre. Thus, texts of diverse genres can be generated on the basis of the same plot.

\section{Why Lyric Song?}

The answer to the original question, why lyric poetry became a preferred form of expression for the controversies of the late Middle Ages, can be found in the specific qualities of this genre. Musical form seems to be essential to the German art of song of the fifteenth and sixteenth centuries, because these continue to be sung (as indicated by the fact that the melody is increasingly recorded) and are thus in competition with unsung speech (in prose). In addition, the strophic form (the dôn), a literary phenomenon independent of text and melody, plays an increasing role in the lyric poetry of the late Middle Ages. This can be shown by the growing number of firmly established and very 
widespread stanza blueprints (for example Hildebrand's dôn, the Herzog Ernst dôn or the Lindenschmidt dôn) which cannot only be linked to different texts, but also to different melodies.

In German lyric poetry of the late Middle Ages, this elaborate harmony of text, dôn and melody generates a rich and elaborate store of retextualization types, which both authors and recipients know very well. These then led to characteristic semanticizations of melodies and forms of stanzas, which therefore serve as discourse markers indicating that a song adheres to a complex of themes (such as political and social events).

In the case of the droll song about the clever peasant, the combination of strophic structure and melody seems to have become a real metrical signature for a world turned upside down. It is typical that these forms of retextualization can link very different texts, dône, and melodies in loose clusters which are bound together in terms of not only form (using the same metric structures and melodies), but also content. Pre-texts and re-texts are interconnected by semantic bridges, which work on the principles of similarity, but also of explicit opposition or hyperbole.

\section{Bibliography}

\section{Primary Literature}

65 deutsche Lieder. Für vier- bis fünfstimmigen gemischten Chor a cappella nach dem Liederbuch von Peter Schöffer und Mathias Apiarius (Biener) (Straßburg spätestens 1536). 1967, ed. H.J. Moser. Wiesbaden.

Altdeutsches Liederbuch. Volkslieder der Deutschen nach Wort und Weise aus dem 12.

bis zum 17. Jahrhundert, 2 vols. 2010. ed. F.M. Böhme. Hildesheim, reprint of the original edition 1877 .

Das Ambraser Liederbuch vom Jahre 1582. 1962, ed. J. Bergmann. Stuttgart (Bibliothek des Literarischen Vereins in Stuttgart 12), reprint Hildesheim.

Amoreuse liedekens. 1984, ed. J. Klatter. Amsterdam.

Antwerpener Liederbuch vom Jahre 1544. 1968, ed. A.H. Hoffmann von Fallersleben. Amsterdam (Horae Belgicae 11), reprint of the original edition 1855 .

Het Antwerps Liedboek. A critical edition. 1983, ed. H. Joldersma. Ann Arbor, Michigan. Het Antwerps Liedboek. 2004, 2 vols., ed. D. van der Poel, and L.P. Grijp et al. Tielt. Samuel Coster's werken. 1883, ed. R.A. Kollewijn. Haarlem.

Volks- und Gesellschaftslieder des XV. und XVI.Jahrhunderts. Bd. I. Die Lieder der Heidelberger Handschrift Pal. 343. 1905, ed. A. Kopp. Berlin (Deutsche Texte des Mittelalters 5).

Das Deutsche Kirchenlied von Martin Luther bis auf Nicolaus Herman und Ambrosius 
Blaurer. 1841, ed. Ph. Wackernagel, Erste Abtheilung. Stuttgart (http://www.mdz-nbn -resolving.de/urn/resolver.pl?urn=urn:nbn:de:bvb:12-bsb11105578-9 accessed on 23 April 2018).

Deutscher Liederhort. Auswahl der vorzüglicheren deutschen Volkslieder nach Wort und Weise aus der Vorzeit und Gegenwart. 1988, 3 vols., ed. L. Erk, and F.M. Böhme, vol. 1. Hildesheim, reprint of the original edition 1893-1894

Een devoot ende profitelyck boecxken. 1889, ed. and comm. D.F. Scheurleer. 's-Gravenhage.

Jörg Dürnhofers Liederbuch (um 1515). Faksimile des Lieddruck-Sammelbandes Inc. 1446a der Universitätsbibliothek Erlangen. 1993, ed. F. Schanze. Tübingen (Fortuna vitrea. 11).

Georg Forster, Frische teutsche Liedlein (1539-1556). Teil 1-5. 1964-1997, ed. K. Gudewill et al., Wolfenbüttel (Das Erbe deutscher Musik 20: Abteilung Mehrstimmiges Lied $3 / 5 / 6 / 7 / 8)$.

Georg Forster, Frische Teutsche Liedlein in fünf Teilen. Abdruck nach den ersten Ausg. 1539, 1540, 1549, 1556 mit den Abweichungen der späteren Drucke. 1903. ed. E. Marriage. Halle (Neudrucke deutscher Litteraturwerke des XVI. und XVII. Jahrhunderts 203-206).

Das Glogauer Liederbuch. 1973, ed. H. Ringmann in collaboration with J. Klapper, 2 parts. Kassel etc., reprint of the original edition 1936-1936.

KLD = Deutsche Liederdichter des 13. Jahrhunderts. 1978, ed. C. von Kraus, and G. Kornrumpf. Berlin etc.

Adam Reißner. Gesangbuch. 2004, ed. and comm. J. Janota in collaboration with U. Evers. 2 vols. Tübingen (Studia Augustana 12).

Das Rostocker Liederbuch. Nach den Fragmenten der Handschrift. 1927, ed. F. Ranke, und J. Müller-Blattau. Halle (Schriften der Königsberger Gelehrten Gesellschaft. Geisteswissenschaftliche Klasse, 4. Jahr, Heft 5). Reprinted as: Rostocker Liederbuch. Niederdeutsche Handschrift des 15. Jahrhunderts aus dem Bestand der Universitätsbibliothek Rostock. 1987, Leipzig and Kassel (Documenta musicologica. Handschriften Facsimiles 18).

Wolfgang Schmeltzl, Guter, seltzsamer und kunstreicher teutscher Gesang. 1990, ed. R. Flotzinger. Graz (Denkmäler der Tonkunst in Österreich. 147-148).

Souterliedekens. Een nederlandsch psalmboek van 1540. Met de oorspronkelijke volksliederen die bij de melodieen behooren. 1922, ed. E. Mincoff-Marriage. 's-Gravenhage (Het oude nederlandsche lied 1 ).

Souterliedekens 1540. Facsimile-edition with introduction and notes. 1984, ed. J. van Biezen, and M. Veldhuyzen. Buren (Facsimile of Dutch songbooks 2).

Unbekannte Ausgaben geistlicher und weltlicher Lieder, Volksbücher und eines alten ABCBüchleins gedruckt von Thiebold Berger (Straßburg 1551-1584). 74 Titelfaksimiles in Originalgröße mit 68 Abbildungen. 1911, ed. P. Heitz. Strasbourg. 
Das Weimarer Liederbuch. Schätzbare Sammlung alter Volkslieder. 1976, ed. K. Kratzsch. Leipzig.

\section{Research Literature}

Bax, D. 1935-1936. Uit de geschiedenis van het volkslied 'Een boerman hadde een dommen sin'. Nederlandsch tijdschrift voor volkskunde 40: 10-25.

Berthold, L. 1918. Beiträge zur hochdeutschen geistlichen Kontrafaktur vor 1500, Diss. Marburg 1918 (Printed extract: Marburg 0. J. 1920).

Bienenfeld, E. 1904. Wolffgang Schmeltzl, sein Liederbuch (1544) und das Quodlibet des XVI. Jahrhunderts. Sammelbände der Internationalen Musikgesellschaft 6: 80-135.

Brednich, R.W. 1968. Schwänke in Liedform. In Gedenkschrift für Paul Alpers, eds. H. Röhrig and O. Bernstorf. Hildesheim: 69-9o.

Brednich, R.W. 1973. Schwankballade. In Handbuch des Volksliedes, vol. 1, eds. R.W. Brednich, L. Röhrich, and W. Suppan. München: 157-203.

Brednich, R.W. 1983. Der kluge Bauer. In Die deutsche Literatur des Mittelalters. Verfasserlexikon, 2nd. ed., eds. K. Ruh, and B. Wachinger: Berlin, New York, vol. 4: 12631264.

Bruin, M. de, and J. Oosterman 2001-2002. Repertorium van het Nederlandse lied tot 160o, 2 vols. Gent, Amsterdam (Studies op het gebied van de Cultuur in de Nederlanden 4). Cf. the online presentation http://www.liederenbank.nl/.

Bruns, K. 2008. Das deutsche weltliche Lied von Lasso bis Schein. Kassel, Basel (Schweizer Beiträge zur Musikforschung 10).

Bumke, J., and U. Peters (eds.) 2005. Retextualisierung in der mittelalterlichen Literatur. Berlin (Sonderhefte der Zeitschrift für deutsche Philologie 124).

Curschmann, M. (ed.) 1979. Texte und Melodien zur Wirkungsgeschichte eines spätmittelalterlichen Liedes. Hans Heselloher 'Von üppiglichen dingen'. Bern etc. (Altdeutsche Übungstexte. 20).

Evers, U. 2007. Das geistliche Lied der Schwenckfelder. Tutzing (Mainzer Studien zur Musikwissenschaft 44).

Fink, M., and W. Salmen 1995. Glogauer Liederbuch. In Musik in Geschichte und Gegenwart, ed. L. Finscher. Kassel, Sachteil, vol. 3: 1481-1483.

Flotzinger, R. 2005. Schmeltzl, Wolfgang. In Musik in Geschichte und Gegenwart, ed. L. Finscher. Kassel, Personenteil, vol. 14: 1421-1422.

Gennrich, F. 1965. Die Kontrafaktur im Liedschaffen des Mittelalters. Langen.

Gier, J. de 1987. Van de Souterliedekens tot Marnix. Stromingen en genres binnen de letterkunde der hervorming in de zestiende eeuw. Kampen (Reformatie reeks 21).

Haapalainen, T.I. 1976. Die Choralhandschrift von Kangasala aus dem Jahre 1624. Die Melodien und ihre Herkunft. Åbo (Acta Academiae Aboensis Ser. A 53).

Hennig, K. 1908. Die geistliche Kontrafaktur im Jahrhundert der Reformation. Ein Beitrag zur Geschichte des deutschen Volks- und Kirchenliedes. Diss. Königsberg 1908 (Printed extract: Halle 1909). 
Heller, K., H. Möller, and A. Waczkat (eds.) 200o. Musik in Mecklenburg. Beiträge eines Kolloquiums zur mecklenburgischen Musikgeschichte veranstaltet vom Institut für Musikwissenschaft der Universität Rostock, 24.-27. September 1997. Hildesheim, Zürich, New York (Studien und Materialien zur Musikwissenschaft 21).

Heydeck, K. 2001. Die mittelalterlichen Handschriften der Universitätsbibliothek Rostock. Wiesbaden (Kataloge der Universitätsbibliothek Rostock 1).

Hoffmann-Erbrecht, L. 1964. Thomas Stoltzer. Leben und Schaffen. Kassel (Die Musik im alten und neuen Europa 5).

Holtorf, A. 1992. Rostocker Liederbuch. In Die deutsche Literatur des Mittelalters. Verfasserlexikon, 2nd. ed., eds. K. Ruh, and B. Wachinger: Berlin, New York vol. 8: 253257.

Holzapfel, O. 1998. Religiöse Identität und Gesangbuch. Zur Ideologiegeschichte deutschsprachiger Einwanderer in den USA und die Auseinandersetzung um das 'richtige' Gesangbuch. Bern etc. (Deutsche Volkslieder mit ihren Melodien 12).

Holzapfel, O. 20o6. Liedverzeichnis. Die ältere deutschsprachige, populäre Liedüberlieferung (in Zusammenarbeit mit dem Volksmusikarchiv des Bezirks Oberbayern, Bruckmühl). Hildesheim.

Holznagel, F.-J., and H. Möller 2003. Ein Fall von Interregionalität. Oswalds von Wolkenstein "Wach auf, mein hort" (Kl 101) in Südtirol und in Norddeutschland. In Regionale Literaturgeschichtsschreibung. Aufgaben, Analysen und Perspektiven, eds. H. Tervooren and J. Haustein. Berlin (Sonderheft der Zeitschrift für deutsche Philologie 122): 102-133.

Holznagel, F.-J. 2005. Habe ime wîs und wort mit mir gemeine... Retextualisierungen im Bereich der deutschsprachigen Lyrik des Mittelalters. Eine Skizze. In Retextualisierung in der mittelalterlichen Literatur, eds. J. Bumke and U. Peters. Berlin (Sonderhefte der Zeitschrift für deutsche Philologie 124): 47-81.

Holznagel, F.-J. 2007. Der Martin verkert, geistlich. Zum Trinklied W 54* des Mönchs von Salzburg und seinen geistlichen Kontrafakturen (Heinrich Laufenberg WKL 795 und 796; Hohenfurter Liederbuch Nr. 75). In Mit clebeworten underweben. Festschrift für Peter Kern zum 65. Geburtstag, ed. T. Bein. Frankfurt a. Main etc.: 193-212.

Holznagel, F.-J. (in collaboration with A. Bieberstedt, U. Kühne, and H. Möller) 2010. Das "Rostocker Liederbuch" und seine neue kritische Edition. Niederdeutsches Jahrbuch 133: 45-86.

Holznagel, F.-J. (in collaboration with H. Möller, A. Bostelmann, and D. Brandt) 2013. Zirkulationen. Zur Wirkungsgeschichte eines spätmittelalterlichen Schwankliedes. In Grundlagen. Forschungen, Editionen und Materialien zur deutschen Literatur und Sprache des Mittelalters und der Frühen Neuzeit, eds. R. Bentzinger, U.-D. Oppitz, and J. Wolf. Stuttgart: 417-438.

Holznagel, F.-J. Digitales Archiv zum Rostocker Liederbuch (www.rostocker-liederbuch .de). 
Houtsma, J. 2002. Het lied van de boerman. Tijdschrift voor Nederlandse Taal- en Letterkunde 18: 151-160.

Kadelbach, A. 1976. Das erste Schwenckfelder-Gesangbuch, Germantown 1762, und seine Entstehung. Jahrbuch für Liturgik und Hymnologie 20: 176-179.

Knuttel, J.A.N. 1974. Het geestelijk lied in de Nederlanden voor de Kerkhervorming, Groningen, Amsterdam, reprint of the 1906 edition.

Koepp, J. 1929. Untersuchungen über das Antwerpener Liederbuch vom Jahre 1544. Antwerpen.

Kugler, H. 1991. Schrot, Schrott, Martin (Michael). In Literaturlexikon. Autoren und Werke deutscher Sprache, ed. W. Killy. Gütersloh etc. vol. 10: 407-408.

Lenselink, S.J. 1959. De Nederlandse psalmberijmingen in de 16 e eeuw van de Souterliedekens tot Datheen met hun voorgangers in Duitsland en Frankrijk. Assen.

Lipphardt, W. 1967. Über die Begriffe Kontrafakt, Parodie, Travestie. Jahrbuch für Liturgik und Hymnologie 12: 104-111.

Mertens, V. 2005. Ach hülff mich leid. Zur geistlichen Kontrafaktur weltlicher Lieder im frühen 16. Jahrhundert. In Gattungen und Formen des europäischen Liedes vom 14. bis zum 16. Jahrhundert, eds. M. Zywietz, V. Honemann and C. Bettels. Münster (Studien und Texte zum Mittelatler und zur frühen Neuzeit 8): 169-188.

Meyer, D.H. 1989. Literarische Hausbücher des 16. Jahrhunderts. Die Sammlungen des Ulrich Mostl des Valentin Holl und des Simprecht Kröll, vols. 1-2, Würzburg (Würzburger Beiträge zur deutschen Philologie 2,1-2).

Mone, F.-J. 1837. Notizen über Volkslieder 1. Anzeiger für Kunde der teutschen Vorzeit 6: 170-171.

Pelnar-Zaiko, I. 1984. Deutsche Liedkontrafaktur im 15. Jahrhundert. In Lyrik des ausgehenden 14. und 15. Jahrhunderts, ed. V. Spechtler. Amsterdam (Chloe 1): 161-172.

RSM = Repertorium der Sangsprüche und Meisterlieder 1986-2010. ed. H. Brunner, and B. Wachinger, in collaboration with E. Klesatschke and F. Schanze, vol. 1-16. Tübingen.

Roth, K. 1977. Ehebruchschwänke in Liedform. Eine Untersuchung zur deutsch- und englischsprachigen Schwankballade. München. (Motive. Freiburger Folkloristische Forschung 9).

Ruberg, U. 1984. Contrafact uff einen geistlichen sinn. Liedkontrafaktur als Deutungsweg zum Spiritualsinn. In Geistliche Denkformen in der Literatur des Mittelalters, ed. K. Grubmüller. München (Münstersche Mittelalter-Schriften 51): 69-82.

Sappler, P. 1981. Glogauer Liederbuch. In Die deutsche Literatur des Mittelalters. Verfasserlexikon, 2nd. ed., eds. K. Ruh, and B. Wachinger: Berlin, New York, vol. 3: 57-59.

Scheurleer, D.F. 1977. Die Souterliedekens. Beitrag zur Geschichte der ältesten niederländischen Umdichtung der Psalmen. Utrecht (Utrechtse herdrukken 16), reprint of the 1898 edition.

Schiendorfer, M. 1995. Der Wächter und die Müllerin "verkêrt”, “geistlich”. Fußnoten zur 
Liedkontrafaktur bei Heinrich Laufenberg. In Contemplata aliis tradere. Studien zum Verhältnis von Literatur und Spiritualität, eds. C. Brinker et al. Bern etc.: 273-316.

Schmidt-Beste, T. 2006. Stoltzer, Stolczer, Stolcer, Scholczer, Thomas. In Musik in Geschichte und Gegenwart, ed. L. Finscher. Kassel, Personenteil, vol. 15: 1538-1544.

Staehelin, M. 2003. Musikhandschrift und Musikdruck in der ersten Hälfte des 16. Jahrhunderts. In Die Gleichzeitigkeit von Handschrift und Buchdruck im 15. und 16. Jahrhundert, eds. G. Dicke and K. Grubmüller. Wiesbaden (Wolfenbütteler Mittelalterstudien 16): 229-261.

Tervooren, H. 20o6. Van der Masen tot op den Rijn. Ein Handbuch zur Geschichte der mittelalterlichen volkssprachlichen Literatur im Raum von Rhein und Maas. Berlin.

Verweyen, T., and G. Witting 2000. Kontrafaktur. In Reallexikon der deutschen Literaturwissenschaft, eds. H. Fricke et al. Berlin, New York, vol. 2: 337-340.

Wachinger, B. 1985. Heinrich Laufenberg. In Die deutsche Literatur des Mittelalters. Verfasserlexikon, 2nd. ed., eds. K. Ruh, and B. Wachinger: Berlin, New York, vol. 5: 614625 .

Wachinger, B. 1985. Lindenschmidt. In Die deutsche Literatur des Mittelalters. Verfasserlexikon, 2nd. ed., eds. K. Ruh, and B. Wachinger: Berlin, New York, vol. 5: 840-841.

Williams, C.A. 1930. Der hochdeutsche Text des Liedes 'Die welt die hat ein thummen mut'. Jahrbuch für Volksliedforschung 2: 143-145.

Winkelman, J. 2003. Ploegende boeren, barende akers. Over liederlijke Vlaamse liedekens en laatmiddeleeuwse erotische insignes. Nederlandse letterkunde 8: 10-23.

Wiora, W. 1953. Die Melodien der "Souterliedekens" und ihre deutschen Parallelen. In Internationale Gesellschaft für Musikwissenschaft. Fünfter Kongress Utrecht 3. bis 7. Juli 1952. Amsterdam: 438-449. 